\title{
Fertility in a male with trisomy 21
}

\begin{abstract}
RICHARD SHERIDAN*, JUAN LLERENA JR*, SALLY MATKINS*, PAUL DEBENHAM $\dagger$, ANDREW CAWOOD $\dagger$, AND MARTIN BOBROW* From * the Paediatric Research Unit, Division of Medical and Molecular Genetics, United Medical and Dental Schools of Guy's and St Thomas's Hospitals, London SE1 9RT; and †Cellmark Diagnostics, ICI Chemical Industries plc, Blacklands Way, Abingdon, Oxfordshire OX14 1DY.
\end{abstract}

SUMmARY We review the published reports on reproduction in cases of non-mosaic trisomy 21 (Down's syndrome) and present the first fully documented case of a non-mosaic male with Down's syndrome fathering a pregnancy, a fact which has important implications in the light of caring for these people in the community.

The Down's syndrome female has ovaries containing a reduced number of small follicles, which have a greatly increased rate of atresia. ${ }^{1}$ Twenty-six nonmosaic trisomy 21 females, in 29 pregnancies, have produced 10 offspring with Down's syndrome, two spontaneously aborted fetuses whose status could not be evaluated, and 18 (including one monozygotic twin pair) chromosomally normal offspring. Of these, two are mentally retarded, four have other congenital malformations, and three were either spontaneously aborted or died of prematurity (table 1). Older published references describe a further seven women with nine offspring (table 2), although insufficient data are available to evaluate these.

Male Down's syndrome patients are often well masculinised, but are said to be infertile. Jagiello ${ }^{42}$ reported six adult male subjects showing normal serum testosterone levels in five of the six, normal testicular size in three, raised $\mathrm{LH}$ in five, and raised FSH in two patients. Benda ${ }^{43}$ commented that Down's syndrome males very often have small testes and that spermatogenesis was only rarely present. Stearns $e t \mathrm{al}^{44}$ showed a complete absence of sperm in four out of nine patients and only occasional spermatozoa in the other five.

Histology performed on Down's syndrome testes usually shows markedly decreased spermatogenesis. ${ }^{45}$ The inability of Down's syndrome males to reproduce may be related to their sexual impotence as well as to their inability to produce sufficient gametes. ${ }^{46}$

Mosaic Down's syndrome can be associated with fertility in the male, as the germ cell line can contain normal cells. Thompson, ${ }^{18}$ describing case 10

Received for publication 3 August 1988.

Revised version accepted for publication 9 November 1988. (table 1), states that "there appears to have been reason to believe that the father was also a mongol, but this cannot be confirmed". Other than this very brief anecdotal aside, we can find no reference in published reports to a non-mosaic male with trisomy 21 who has fathered a child.

\section{Case report}

Our patient is a 29 year old man with trisomy 21 , showing some of the classical features of Down's syndrome: low intelligence, short stature, low set ears, epicanthic folds, large tongue, and clinodactyly. His mother was aged 24 at the time of his birth and he is the oldest of five sons.

He lives in special local authority housing with three other mentally retarded adults. He developed a relationship with a girl, living in the same house, who is educationally subnormal with no specific medical diagnosis. She had been on oral contraception, but had recently stopped this. The couple were referred after eight weeks of amenorrhoea. A singleton pregnancy was confirmed by ultrasound scanning.

They had had unprotected sexual intercourse for three months before they were seen in the clinic and it therefore seems likely that she conceived the pregnancy during her first unprotected cycle.

The couple were counselled in the presence of their social worker. They were told that there was a significant risk of the baby being severely handicapped. They themselves decided that they would not want to bring up a handicapped child and that they wanted prenatal diagnosis.

All parties present agreed that the couple had understood the situation and that they had given informed consent. 
TABLE 1 Reproduction in non-mosaic Down's syndrome females.

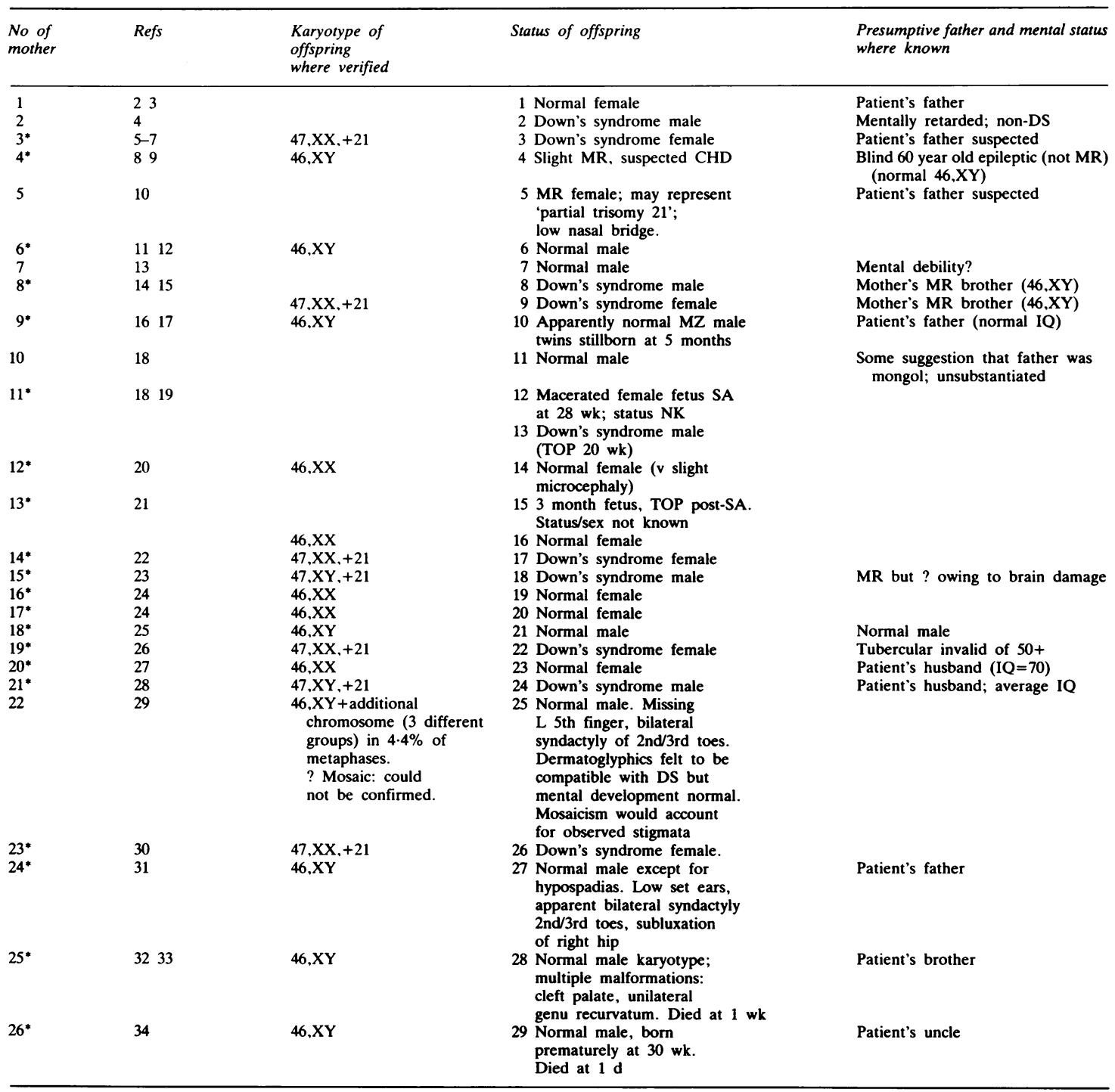

*Mother's karyotype verified cytogenetically.

A transcervical CVS was carried out. ${ }^{47}$ Unfortunately, some two weeks after the procedure, the woman experienced some bleeding, which settled on admission to hospital. However, the couple were sexually active throughout the post CVS period, and although this was found to exacerbate the bleeding, it was not possible to persuade them to cease. After further episodes of bleeding over the next six weeks, she lost the pregnancy some nine weeks after the CVS procedure.
Pathological examination (Dr M J Seller) showed a fetus of a physical size compatible with 16 to 17 weeks of gestation with no external or visceral anomalies.

\section{Results and discussion}

$\mathrm{G}$ banded chromosome analysis of the man showed a chromosome complement of $47, \mathrm{XY},+21$ in 51 lymphocyte metaphases examined and in 101 meta- 
TABLE 2 Very early reports of reproduction in Down's syndrome.

\begin{tabular}{|c|c|c|c|c|}
\hline No & Source & Ref & $\begin{array}{l}\text { Karyotype } \\
\text { where known }\end{array}$ & Status \\
\hline 1 & Pogue (1917) & 735 & Normal & $\begin{array}{l}\text { (a) SA 4-5 months } \\
\text { (b) Normal child, sex not known }\end{array}$ \\
\hline 2 & Lind (1923) & 736 & NK & Caesarian section, status/sex NK \\
\hline 3 & Weygandt (1936) & 737 & NK & $\begin{array}{l}\text { Mother said to have had an abortive form of } \\
\text { 'mongolism'. Pictures suggest 'mongolism': } \\
\text { fissured tongue, hyperextensible joints, low IQ. } \\
\text { No further details of mother or child }\end{array}$ \\
\hline 4 & Allen and Baroff (1955) & 63839 & & $\begin{array}{l}\text { Describes } 4 \text { reports. Oster }{ }^{39} \text { says that } \\
\text { diagnosis was uncertain in } 2 \text {, Forsmann and } \\
\text { Thysell }^{8} \text { say that only } 1 \text { was convincing }\end{array}$ \\
\hline 5 & Rosenberg (1924) & 840 & $\begin{array}{l}\text { Normal } \\
\text { Normal }\end{array}$ & $\begin{array}{l}\text { Married 'mongolian' woman }+2 \text { normal children } \\
\text { No further details known; Forsmann and Thysell } \\
\text { say diagnosis should be disregarded because } \\
\text { he had unconventional views regarding } \\
\text { 'transitional types of DS' }\end{array}$ \\
\hline 6 & Holt (1949) & 4 & $\begin{array}{l}\text { Non-mongol } \\
\text { Non-mongol }\end{array}$ & $\begin{array}{l}\text { An undisputed mongol, with typical facies and } \\
\text { hand formation }\end{array}$ \\
\hline 7 & Orel (1926) & 441 & Normal & No further details \\
\hline
\end{tabular}

phases from a skin biopsy. His partner had a normal female 46,XX chromosome complement. Chromosome analysis, after chorionic villus sampling (CVS), showed the fetus to have a normal male chromosome complement $(46, \mathrm{XY})$.

In order to confirm paternity, DNA 'fingerprint' patterns ${ }^{48}$ were analysed from the CVS sample and both parents.

DNA was digested with 80 units of HinfI for four hours at $37^{\circ} \mathrm{C}$, run at $2.5 \mathrm{~V} / \mathrm{cm}$ in $0.7 \%$ agarose until a $2.3 \mathrm{kbp}$ marker had run $20 \mathrm{~cm}$, then transferred to nylon membranes (Hybond-N, Amersham), and probed with probes 33.6 and $33 \cdot 15^{49}$ (figure). The results from the two probes were combined to calculate the probability of the man with Down's syndrome being the true father of this pregnancy.

The number of bands recorded in the mother was 53 , the same as the putative father. The number analysed in the fetus was 55 . Of these 55 , the number of bands shared with the mother was 32 , and the number shared exclusively with the putative father was 22 . In addition, there was one unassigned band. Therefore, the DNA 'fingerprint' of the fetus contained 23 non-maternal bands in the region analysed. Of these, 22 were found to have the same 'fingerprint' as the putative father.

These results provide three possible hypotheses.

(1) Paternity is correct and the undefined band is a new mutation of one of the parental bands; the probability for this is calculated to be $0 \cdot 1978$.

(2) The putative father is a first degree relative of the true father; the probability for this is $2.989 \times 10^{-4}$.

(3) The putative father is unrelated to the true father, with a probability of $9.948 \times 10^{-13}$.

We decided, therefore, that the last hypothesis

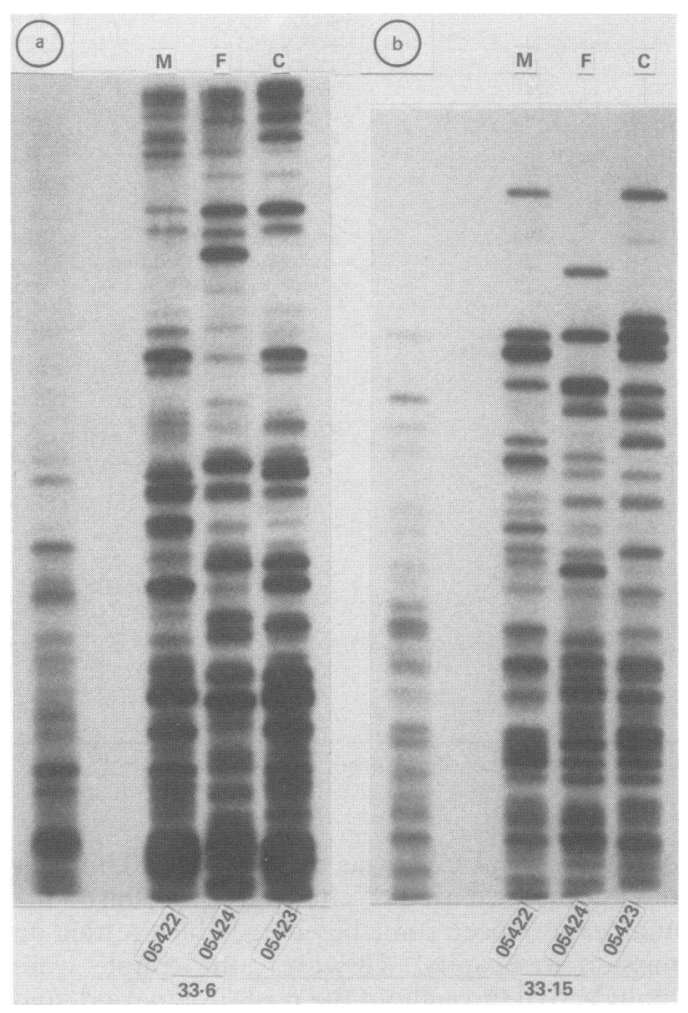

FIGURE 'DNA fingerprint' gels from Down's syndrome male (track M), his female partner (track F), and the chorion villus sample from their pregnancy (track $C$ ), using two different hypervariable probes $33.6(a)$ and $33 \cdot 15(b)$. 
can be rejected. The relative likelihood of hypotheses 1 and 2 is 661.8 to 1 .

It is exceedingly unlikely that any of the man's relatives could be the father, and we therefore concluded that our patient was indeed the father of this pregnancy.

Further evidence of paternity was provided in a comparison of the cytogenetic analysis of the CVS sample and chromosomes from the father's blood. The QFQ staining technique was used to compare the chromosomes of our patient and the fetus. These showed similar looking intermediate (size three) $\mathrm{Y}$ chromosomes and a brilliant basal segment on the short arm of chromosome 22 (p11.20-p12.00 with intensity five). ${ }^{50}$

This would appear to be the first documented example of a pregnancy fathered by a male with apparently non-mosaic trisomy 21 . Paternal mosaicism cannot, by definition, be excluded, but with 152 cells analysed a $2 \%$ mosaicism can be excluded with $95 \%$ confidence. ${ }^{51}$ It may well be that an undetected normal cell line is responsible for this man's fertility, but from a practical cytogenetic viewpoint this mosaicism could not have been predicted before the pregnancy, and caution should therefore be exercised in advising people responsible for the care of adults with this condition about possible fertility.

\section{Conclusion}

This observation emphasises the need to maintain adequate contraceptive cover, especially as more mentally handicapped adults are removed from supervised institutions and encouraged to live within the community.

We would like to thank The Generation Trust and The Spastics Society for their financial support of the work which contributed to this paper. $\mathrm{Mr}$ Richard Sheridan is supported by a LORS grant, and Dr Juan Llerena Jr is supported by Action Research for the Crippled Child.

\section{References}

${ }^{1}$ Hojager B, Peters H, Byskov AG, Faber M. Follicular development in ovaries of children with Down's syndrome. Acta Paediatr Scand 1978;67:637-43.

2 Sawyer GM. Case report: reproduction in a mongoloid. Am J Ment Defic 1950;54:204-6.

3 Sawyer GM, Shafter AJ. Reproduction in a mongoloid: a follow-up. Am J Ment Defic 1957;61:793-5.

${ }^{4}$ Lelong M, Borniche P, Kreisler L, Baudy R. Mongolien issu de mère Mongolienne. Arch Fr Pediatr 1949;6:231-8.

5 Rehn AT, Thomas E. Family history of a mongoloid girl who bore a mongoloid child. Am J Ment Defic 1957;62:496-9.

6 Stiles KA, Goodman HO. Reproduction in a mongoloid. Acta Genet Med Gemellol (Roma) 1961;10:457-69.

7 Johnston AW, Jaslow RI. Children of mothers with Down's syndrome. N Engl J Med 1963;269:439-43.
${ }^{8}$ Forssmann H, Thysell T. A woman with mongolism and her child. Am J Ment Defic 1957;62:500-3.

${ }^{9}$ Forsmann $\dot{H}$, Lehmann O, Thysell T. Reproduction in mongolism. Chromosome studies, and re-examination of a child. Am $J$ Ment Defic 1961;65:495-8.

10 Schlaug R. A mongolian mother and her child. A case report. Acta Genet (Basel) 1957;7:533-40.

1 Levan A, Hsu TC. The human idiogram. Hereditas 1959;45: 665-74.

12 Levan A, Hsu TC. The chromosomes of a mongoloid female, mother of a normal boy. Hereditas 1960;46:770-2.

${ }^{13}$ Mullins DH, Estrada WR, Gready TG. Pregnancy in an adult mongoloid female. Report of a case. Obstet Gynecol 1960;15: 781-3.

14 Hanhart E. Mongoloid Idiotie bei Mutter und zwei Kindern aus Inzesten. Acta Genet Med Gemellol (Roma) 1960;9:112-30.

${ }^{15}$ Hanhart E, Delhanty JDA, Penrose LS. Trisomy in mother and child. Lancet $1961 ; \mathbf{i}: 403$.

${ }^{16}$ Priest JH, Thuline HC, Norby DE, Laveck GD. Reproduction in human autosomal trisomies: chromosome studies of a mongol mother, her non-mongol twins and her family. Am J Dis Child 1963;105:31-41.

17 Thuline HC, Priest JH. Pregnancy in a 14-year old mongoloid. Lancet 1961;i:1115-6.

18 Thompson MW. Reproduction in two female mongols. Can J Genet Cytol 1961;3:351-4.

19 Thompson MW. 21-trisomy in a fertile female mongol. Can J Genet Cytol 1962;4:352-5.

${ }^{20}$ Foxton JRV, Pitt D, Wiener S, Brasch J, Ferguson J. Reproduction in a female with Down's syndrome. Aust Paediatr $J$ $1965 ; 1: 176-7$.

21 Tagher P, Reisman LE. Reproduction in Down's syndrome (mongolism). Chromosomal study of mother and normal child. Obstet Gynecol 1966;27:182.

22 Finley WH, Finley SC, Hardy JP, McKinnon T. Down's syndrome in mother and child. Obstet Gynecol 1968;32:200-1.

23 Friedman JM, Sternberg WH, Varela M, Barclay DL. Trisomy21 in mother and child: report of a case. Obstet Gynecol 1970;36:731-3.

${ }^{24}$ Masterson JG, Law EM, Power MM, Stokes BM, Murphy D. Reproduction in two females with Down's syndrome. Ann Genet (Paris) 1970;13:38-41.

${ }^{25}$ Moric-Petrovic S, Garzicic B. Mother with Down's syndrome and her child. $J$ Ment Defic Res 1970;14:68-76.

${ }^{26}$ Rethoré MO, Lafourcade J, Prieur M, et al. Mere et fille trisomiques 21 libres. Ann Genet (Paris) 1970;13:42-5.

${ }^{27}$ Reiss JA, Lovrien EW, Hecht F. A mother with Down's syndrome and her chromosomally normal infant. Ann Genet (Paris) 1971;14:225-7.

${ }^{28}$ Fuchs-Mecke S, Passarge E. Kinder von Müttern mit Downsyndrome Mongolismus. Dtsch Med Wochenschr 1972;97: 338-41.

29 Scharrer S, Stengel-Rutowiski S, Rodewald-Rudescu A, Erdlen E, Zang KD. Reproduction in a female patient with Down's syndrome. Case report of a 46,XX child showing slight phenotypical anomalies, born to a $47, \mathrm{XX},+21$ mother. Hum Genet 1975;26:207-14.

30 Francesconi D, Gauschino S. Trisomy 21 in mother and daughter. Clin Genet 1976;9:346.

31 Van de Velde-Staquet MF, Breynaert R, Walbaum R, SaintAubert P, Farriaux JP, Fontaine G. La descendance des meres trisomiques 21. A propos d'une observation. J Genet Hum 1973;3:187-206.

32 Grall JY, Le Goux AM, Le Marec B, Picard F, Larget-Piet L, Dubois J. The fertility of trisomy 21 sufferers. Nouv Presse Med 1978;7:2459-60.

33 Le Marec B, Picard F, Larget-Piet L, Le Goux AM, Grall JY, Senecal J. Amniocentese chez une trisomique 21 avec foetus a caryotype normal. Arch Fr Pediatr 1978;35:546-50.

34 Bovicelli L, Orsini LF, Rizzo N, Montacuti V, Bacchetta M. 
Reproduction in Down syndrome. Obstet Gynecol 1982;59: 13-7.

35 Pogue ME. Brief report of 29 cases of mongolian idiocy, with special reference to etiology from standpoint of clinical history, with presentation of three cases. Illinois Med J 1917;32:296-8.

${ }^{36}$ Lind WAT. Observations on mongolian idiocy. Med J Aust 1923;2:272-8.

37 Weygandt W. Der jugendliche Schwachsinn: seine Erkennung, Behandlung und Ausmerzung. Stuttgart: Enke Verlag, 1936.

38 Allen G, Baroff GS. Mongoloid twins and their siblings. Acta Genet (Basel) 1955;5:294-326.

39 Oster J. Mongolism. Op Dom Biol Hum Univ Hafn 1953;32: 1-206.

40 Rosenberg l. Die spateren Schicksale der mongoloiden Kinder. Wien Med Wochenschr 1924;74:2503-6.

41 Orel K. Zur aetiologie des Mongolismus. Z Kinderheilkd 1926;42:440-52.

42 Jagiello G. Reproduction in Down syndrome. In: de la Cruz FF, Gerald PS, eds. Trisomy 21 (Down syndrome). Baltimore: University Park Press, 1981:152.

${ }^{43}$ Benda CE. Down's syndrome, mongolism and its management. New York: Grune and Stratton, 1969.

${ }^{44}$ Stearns PE, Droulard KE, Sabhar FH. Studies bearing on fertility of male and female mongoloids. Am J Ment Defic 1960;65:37-41.
45 Johannisson R, Gropp A, Winking H, Coerdt W, Rehder H, Schwinger E. Down's syndrome in the male. Reproductive pathology and meiotic studies. Hum Genet 1983;63:132-8.

46 Bond DJ, Chandley AC. Aneuploidy. Oxford: Oxford University Press, 1983.

47 Rodeck $\mathrm{CH}$, Nicolaides $\mathrm{KH}$, Morsman JM, McKenzie C, Gosden CM, Gosden JR. A single operator technique for firsttrimester chorion biopsy. Lancet 1983;ii:1340-1.

48 Jeffreys AJ, Wilson V, Thein SL. Hypervariable 'minisatellite' regions in human DNA. Nature 1985;314:67-73.

49 Jeffreys AJ, Wilson V, Thein SL, Weatherall DJ, Ponder BAJ. DNA "fingerprints" and segregation analysis of multiple markers in human pedigrees. Am J Hum Genet 1986;39:11-24.

so Harnden DG, Klinger HP, eds. ISCN: an international system for human cytogenetic nomenclature. Basel: Karger, 1985.

51 Hook EB. Exclusion of chromosomal mosaicism: tables of $90 \%$, $95 \%$, and $99 \%$ confidence limits and comments on use. Am J Hum Genet 1977;29:94-7.

Correspondence to Professor M Bobrow, Paediatric Research Unit, 8th Floor, Guy's Tower, Guy's Hospital Medical School, London SE1 9RT. 